\title{
Selected Reference Books of 1986-87
}

\section{Eileen McIlvaine}

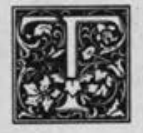

his article follows the pattern set by the semiannual series initiated by the late Constance $\mathrm{M}$. Winchell more than thirty years ago and continued by Eugene P. Sheehy. Although it appears under a byline, the list is a project of the reference departments of Columbia University Libraries, and notes are signed with the initials of the individual staff members. ${ }^{1}$

Since the purpose of the list is to present a selection of recent scholarly and general works of interest to reference workers in university libraries, it does not pretend to be either well balanced or comprehensive. A brief roundup of new editions of standard works is provided at the end of the article. Code numbers (such as AD540, CJ331) have been used to refer to titles in Guide to Reference Books. ${ }^{2}$

\section{BIOGRAPHY}

Women Writers of Spain: An Annotated BioBibliographical Guide. Ed. by Carolyn L. Galerstein. Westport, Conn.: Greenwood, 1986. 389p. \$45 (ISBN 0-31324965-2). LC 86-379.

"The purpose of this annotated bibliography is to create a survey of Spanish women writers' accomplishments as well as to provide brief biographies and a comprehensive list of the authors and their works" (pref.). Three-hundred authors are listed in alphabetical order, and most have written poetry, fiction, and drama, though a few biographers, essayists, and journalists have been included if they treat literary subjects. Each entry provides a short biography followed by an alphabetical list of works. English annotations are provided for many of the works, giving evocative and engaging plot summaries and occasionally the moral of a story. Entries do not include citations to critical books or essays. In addition to a title index, appendixes provide lists of authors by birthdate and language, and a selective list of translations in English, French, German, Italian, and Portuguese.

Women Writers of Spain includes authors writing in Galician and Catalan but does not include women who were born in Spain but did most of their work in Spanish America, or Spanish American women who established their reputations in Spanish America and then moved to Spain. To avoid duplicating two other biobibliographical works, this guide does not include authors listed in Manuel Serrano y Sanz' Apuntes para una biblioteca de escritoras espanolas desde el ano 1401 al 1833 (Madrid, 1903-5) or Quien es quien en las letras espanolas (Guide BD1156) except where new information or a new edition can be added. Despite these guidelines, Women Writers of Spain still spans seven centuries, with thirty authors born before 1800 , forty-two born in the nineteenth century, and more than two hundred born in the twentieth century. It is a good guide that provides both information and the desire to read the books. $-S . S$.

1. Mary Cargill, Anita Lowry, Kirk Moll, Louise Sherby, Sarah Spurgin, Junko Stuveras; Health Sciences Library, Susan Barnes; Lehman Library, Diane Goon; Science Libraries, Mary Kay.

2. Eugene P. Sheehy, Guide to Reference Books, 10th ed. (Chicago: American Library Assn., 1986). 


\section{RELIGION AND MYTHOLOGY}

The Encyclopedia of Religion. Mircea Eliade, editor in chief. New York: Macmillan, [1987]. 15v. (In progress; index forthcoming) $\$ 1,100$ (ISBN 0-02-909480-1).

\section{LC 86-5432.}

For several decades there has been a definite need for an up-to-date, comprehensive encyclopedia of religion in the English language, and it is hoped that this offering from Macmillan will go a long way in meeting that need. In the publisher's tradition of quality encyclopedias, such as the Encyclopedia of Philosophy, (Guide BA75) it features broad essays on the world's religious traditions, themes, and figures, often with shorter entries for biographical articles and narrower topics. The editors' lofty aim in compiling this encyclopedia was "to procure fresh, original articles from the best writers and thinkers and scholars in the world, forming a collection that would accurately reflect what we currently know-or, as one distinguished contributor put it, what we think we know-about the particular histories of religions past and present, great and small, as well as of the general history of religion viewed on a universal scale" (introd.). With this dual emphasis on the detailed study of individual religious traditions and the comparative study of religion through the common themes and ideas of these traditions, the Encyclopedia of Religion is a crowning achievement of the life and scholarship of its late editor, Mircea Eliade, and the History of Religions school of thought.

The signed articles are written by scholars in their respective disciplines, under the editorial supervision of a stellar cast of scholars. They generally provide an overview of the subject followed by substantial detail on particular aspects of the subject, including at least minimal bibliographic information for further research. The general orientation is toward the student and nonspecialist, though the sheer magnitude of information provided and topics covered make it a valuable resource for scholars in the field as well. It is unfortunate that more detailed bibliographic information has not been provided, thereby limiting its usefulness to more advanced users. Also, the index volume, which will greatly enhance the value of the set, is still forthcoming (promised for some time in 1987). Only when it is available will it be clear whether the Encyclopedia provides the same level of extraordinarily detailed information available in the old standard work, Hastings' Encyclopedia of Religion and Ethics (Guide BB51).

At the very least, this encyclopedia will be of great importance to students and nonspecialists as a starting place for research on most topics in religious studies, as well as providing all users with a wealth of information about the religious traditions of the world.-K.M.

Gorman, G. E., and Lyn Gorman. Theological and Religious Reference Materials, v.1-3. Bibliographies and Indexes in Religious Studies, 1,2,7. Westport, Conn.: Greenwood Pr., [1984-86]. (in progress). LC 83-22759.

Contents: v.1. General Resources and Biblical Studies (\$49.95); v.2, Systematic Theology and Church History (\$47.50); v.3, Practical Theology (\$49.95).

With the completion of three volumes of their planned four-volume set, G. E. and Lyn Gorman have produced a monumental guide to theological and religious reference literature (for volume 1, see Guide BB12). It is a comprehensive annotated bibliography to some 5,865 items, primarily nineteenth- and twentieth-century works written in the major Western languages. Volume 1 covered an area that already had relatively good bibliographic coverage, volumes 2 and 3 provide much needed access to the fields of theology, liturgy and worship, art and architecture, music, homiletics, education, counseling, and sociology. While many of these fields (especially those outside theology directly) have their own bibliographies, there has never before been so comprehensive a guide from a religious studies perspective.

The items are organized under broad topical divisions (i.e., church history, bibliographies, dictionaries, handbooks) with alphabetic arrangement within each division. Author, title, and subject in- 
dexes are provided. The clear and concise annotations show a high degree of objectivity in the description of materials whose viewpoints and perspectives cover the whole theological and scholarly spectrum. While generally descriptive in approach, evaluative and even cautionary statements are often included. A wide range of materials is covered: from the standard fare of encyclopedias and bibliographies to an array of introductions, grammars, histories, companions, handbooks.

This is a work of major importance due largely to its comprehensive scope. Few reference works cover the wide variety of viewpoints (and, in this field, theological perspectives) with the careful analysis demonstrated here; nor do many others, within their scope, include all the types of reference tools found here. Yet this comprehensiveness compounds the problems of its arrangement. The work is just too large and detailed to be arranged under broad subject headings. Though the subject indexes are competently prepared, they cannot effectively provide the kind of help supplied by a classified arrangement. This is complicated by the fact that each volume has its own index and that for many topics multiple volumes will need to be consulted. Students and researchers will still generally need to use works like Robert Kemple's Reference Works for Theological Research (with 1986 supplement) (Guide BB222) before consulting the Gorman volumes.

Criticisms aside, this work should take its place as a major theological reference tool for many years to come. Supplements and a fourth volume (comparative and non-Christian religions) are promised, and the authors and publisher are urged to consider a cumulative index to the set. Finally, if a second edition is eventually undertaken, it is hoped that serious consideration will be given to a major reorganization of the contents so that it can take its rightful place as one of the most important religious reference works. $-K . M$.

Hart, George. A Dictionary of Egyptian Gods and Goddesses. London: Routledge \& Kegan Paul, 1986. 229p. £12.95.
(ISBN 0-7102-0965-7). LC 85-11862.

The author, a staff lecturer on the Bronze Age and Egyptian collections for the British Museum's Education Service, has "tried to include all the important deities that figure in magical medicine and daily life" of ancient Egypt (pref.). The entries are arranged alphabetically and often include line illustrations. This book invites comparison with the more lavishly illustrated Gods and Symbols of Ancient Egypt by Manfred Lurker (Guide CF20). Hart's entries are more detailed and informative; his entry on Amun, the Egyptians' supreme god, is thirteen pages, while Lurker gives the god a photograph and twenty-four lines.

Hart also includes a map of ancient Egypt and a selected bibliography. This dictionary will be extremely useful to anyone needing concise and informative material in this area. - M.C.

Religious Periodicals of the United States: Academic and Scholarly Journals. Ed. by Charles H. Lippy. Historical Guides to the World's Periodicals and Newspapers. Westport, Conn.: Greenwood, 1986. 607p. \$65 (ISBN 0-31-3234-20-5). LC 85-9861.

While providing an excellent survey of religious periodical publishing in the United States, this guide also gives the reader an interesting view of American religious history through its description of the people and events that shaped the history of the nation's leading religious periodicals. It includes essays on "more than 100 periodicals and journals in the field of religion" and "concentrates on a sampling of those that focus on academic and scholarly concerns" (pref.). In addition, many general-interest periodicals in the field (with a mixture of scholarly and popular articles) are covered as well. The publications range from the journals of academic and professional societies to those of seminaries and universities, and the wide variety of religious (mostly Christian) denominations. These include current journals as well as those that have ceased publication.

The body of the text is composed of a collection of signed, scholarly essays that 
survey the history and development of the individual journals and discuss their significance in American religious history. Appended to each essay is a list of information sources (bibliography, index sources, reprinted editions, and selected locations) and details of publication history (title changes, volume and issue data, publisher's location, editors, and estimated circulation figures-all with corresponding dates). These detailed lists of bibliographic and publishing information provide students and scholars with a tremendous source of information concerning the history of American religious publishing. The thorough listing of editors is a particularly interesting feature that will aid the study of religious scholarship. (This feature would have been strengthened by complete indexing of the names, rather than only indexing them if they appear in the body of the essays.)

Through his preface and introduction, Lippy provides readers with a brief but helpful introduction to the subject. Other features are a chronological list of the founding dates of the journals with a parallel list giving important events in American religious history and a listing by sponsoring organization or religious tradition. It also includes an author/title/subject index and good cross-referencing from former titles. $-K . M$.

\section{LITERATURE}

The Arthurian Encyclopedia. Ed. by Norris J. Lacy. Garland Reference Library of the Humanities, v.585. New York: Garland, 1986. 649p. \$60 (ISBN 0-82408745-3). LC 84-48864.

Combining brief entries with essays, this encyclopedia lists 723 Arthurian subjects ranging from Agravaine to Zifar, $\mathrm{Li}$ bro del Caballero and covering literature, history, archaeology, art, film, music, and other media. Essays treat major authors and texts, including Malory, Sir Gawaine and the Green Knight, and Gottfried von Strassburg, as well as broader subjects such as heraldry, visual arts, and the origins of the Arthur legend.

Entries are signed, and each is followed by a very brief bibliography of one to four citations. A select bibliography at the beginning of the book lists seven pages of citations in six general categories. The Arthurian Encyclopedia is illustrated with plates showing illuminated manuscripts, pre-Raphaelite illustrations, and the ruins of Tintagel, Glastonbury Abbey, and Cadbury Castle. Cross-references and a list of the entries by categories including arts, French literature, places, themes, and motifs compensate fairly well for the lack of a subject index. This is a good, scholarly encyclopedia discussing the Arthur legend from earliest tales and texts to the present. It is recommended for academic libraries of all sizes. $-S$.S.

Champion, Larry S. The Essential Shakespeare: An Annotated Bibliography of Major Modern Studies. Boston: G. K. Hall, [1986]. 463p. \$55 (ISBN 0-8161-8731-2). LC 86-9994.

This bibliography annotates "what is generally accepted as essential Shakespearean scholarship" (pref.). More than 1,500 entries published in English from 1900 through 1984 are listed in sections on general studies, poems and sonnets, English histories, comedies, tragedies, and romances, which are further subdivided to include reference works, editions, textual studies, criticism, and stage history. In addition to the comprehensive subject and author indexes, there are crossreferences following each section and many of the entries.

Students will love this bibliography. It gives full citations-without any abbreviations-and also lists reprinted essays. The annotations are concise, well written, and fulfill Champion's intention to "clearly reflect the content in sufficient detail to provide helpful guidance for more selective reading" (pref.). Those seeking more extensive criticism of a particular play or theme will find more comprehensive bibliographies cited in the reference sections for each play, but this is an excellent guide for the student seeking "a few good essays." The Essential Shakespeare is recommended for libraries of all sizes.

This reviewer would like to know, mostly for curiosity's sake, how Cham- 
pion arrived at "what is generally accepted as essential Shakespearean scholarship" but has no criticism of the books and articles cited.-S.S.

Dolbow, Sandra W. Dictionary of Modern

French Literature, from the Age of Reason through Realism. Westport, Conn.: Greenwood Pr., 1986. 365p. \$45.95 (ISBN 0-3132-3784-0). LC 85-15492.

This dictionary covers the period from 1715 to 1880 , the year of the death of Flaubert. Some three hundred entries deal with author biographies, synopses, and discussion of the significance and influence of major works, literary movements, and terms. A short bibliography accompanies each entry. The criteria for selecting the bibliographic section, "current and readily accessible," seems to have curtailed the inclusion of some more important foreign works. A companion volume is planned for the subsequent period under the title Dictionary of Modern French Literature from Naturalism and Symbolism to Post-Modernism. A short chronological table and a classified list of the topics are included as well as a detailed index. This is not a cooperative enterprise, but a work by one person.

Some entries succeed in bringing out a feel for the subject, author, or work, others do not go beyond the enumeration of dates and titles (for example, the fourpage entry on George Sand). The bibliographies, which seem to list Englishlanguage works exclusively, include a number of articles and conference papers. If the editor's intention was to serve basically non-French speaking students, it would have been better to list also standard translations of French works discussed in the dictionary. This work would be useful as the starting point of research in French literature for college students.J.S.

Halton, Thomas P., and Stella O'Leary. Classical Scholarship: An Annotated Bibliography. White Plains, N.Y.: Kraus Intl. Pub., [1986]. 396p. \$110; paper, \$45 (ISBN 0-5273-7436-9). LC 82-48984.

Martin McGuire issued a syllabus, Introduction to Classical Scholarship, for his students at Catholic University in 1955, which was so useful it was revised and distributed more widely in 1961. Halton and O'Leary's Classical Scholarship, intended as an update of McGuire, is actually a bibliography and not a syllabus. As such, it too is extremely useful.

The newer work is arranged into fifteen major subject areas, then subdivided into smaller topics. Entries are arranged alphabetically within each section, and each is numbered to make indexing easier. The cut-off date is 1980 for most of the books, the occasional essay, and journals and journal articles cited, with a later work cited if significant. Each entry is very full with complete bibliographical information including earlier and later editions, pagination and number of plates, reprints, series notes, citations to book reviews (from L'Année Philologique), and a good annotation pointing up the work's usefulness.

There are a few curious omissions, e.g., the Kataloge of the Deutsches Archäologisches Institut. The volume concludes with an author index and a detailed subject index; it could have used a title, or at least an anonymous title, index.

This is an excellent reference aid for anyone working in this field both because of the useful arrangement, good annotations, and-despite its seven-year time lag-the range of works selected for inclusion.-E.M.

Postmodern Fiction: A Bio-Bibliographical Guide. Ed. by Larry McCaffery. Movements in the Arts, no.2. Westport, Conn., Greenwood, [1986]. 604p. \$75 (ISBN 0-313-24170-8). LC 85-17723.

In his eighteen-page introduction, the editor succinctly surveys the complex background and development of the theory and practice of postmodern fiction. Without attempting to fit the diverse manifestations of postmodernism into a single definition or mold, his focus in this volume is on "fiction that had rejected traditional notions of representation, mimesis, or realism, or that was attempting to redefine what realism is" (p.xii). For the most part, this encompasses fiction and criticism from the 1960 s to the present and includes both major and minor American and British authors, as well as European 
and Latin American authors who have been translated into English.

The first part of the book consists of fifteen overview articles with selected bibliographies on various aspects of contemporary creative, critical, and theoretical writings; these essays discuss such topics as science fiction, metafiction, experimental realism, magical realism, fiction and the Vietnam War, poetry and fiction, journalism, feminist fiction-all within the context of postmodernist ideas about the nature and experience of literary texts. The second part of the work is devoted to short essays on 102 " authors and critics of postmodern fiction" from Walter Abish to Roger Zelazny, with many better-known figures such as Toni Morrison, Thomas Pynchon, Gabriel Garciá Marquez, and Jacques Derrida in between. Biographical information and critical assessment are followed by a selected bibliography of primary and secondary sources for each author. All articles are signed, and brief notes on contributors are provided.

A selected bibliography of general works of postmodern criticism and an index (primarily of names) complete this hefty volume, which should prove to be a useful, if expensive, guide to the study of nontraditional contemporary literature and literary theory. $-A . L$.

\section{PERFORMING ARTS}

Barnes, Philip, A Companion to Post-War British Theatre. London: Croom Helm, [1986.] 277p. £18.95 (ISBN 0-7099-32006).

This publication is an alphabetical guide to the people and companies that have played important parts in the post-World War II British theater. The emphasis is on playwrights, actors, and actresses, but the author has included some of the more important directors, entries on genre ("Angries," for example), and brief definitions of theatrical terms.

The biographical entries list basic facts, performance highlights, selected critical evaluations, and often include brief bibliographies. The definitions of theatrical terms tend to be cryptic; green room, for instance, is "a waiting room backstage, or sometimes beneath the stage," with no explanation of the origin of the term. An index to the titles mentioned in the entries is included.

Much of the information in this guide can be found in other sources, but this is a convenient, ready-reference source for questions on this period. - M.C.

\section{Carpenter, Charles A. Modern Drama} Scholarship and Criticism 1966-1980: An International Bibliography. Toronto: Univ. of Toronto Pr., [1986]. 587p. \$75 (ISBN 0-8020-2549-8). LC 86-218913.

Developed from the compiler's annual bibliography of modern theater scholarship appearing in Modern Drama, this is a "classified, selected list of publications on world drama since Ibsen" (introd.). It contains some 27,300 entries located in approximately 1,600 journals and between 6,000 to 8,000 books. Materials in nonRoman alphabets and dissertations were excluded. The bibliography emphasizes drama as literature, and thus, as a rule, does not include reviews or discussions of performances. The material is arranged by geographic or linguistic area, then further subdivided by period or subject. Criticism on individual playwrights is listed alphabetically at the end of each section. There are indexes of playwrights and authors.

The depth and scope of this bibliography should be much appreciated by researchers in this field. I would prefer an even more detailed classification system. The criticism for individual playwrights, for example, is listed alphabetically by author, so it is time-consuming to locate criticism of a particular play - the same problem we used to complain about when using the old MLA. The unfortunate, but understandable, lack of a subject index makes locating criticism by themes problematic. But these are minor quibbles about an outstanding reference work.M.C.

Forbes, Fred R. Dance: An Annotated Bibliography, 1965-1982. Garland Reference Library of the Humanities, v.606. New York: Garland, 1986. 261p. \$39 (ISBN 08240-8676-7). LC 85-45150.

This "annotated list of current refer- 
ences on dance in the areas of aesthetics, anthropology, education, history, literature, physiology, psychology, and sociology" (pref.) covers books, articles, book chapters, and dissertations published in English from 1965 to 1982 . Entries are arranged alphabetically by author within each chapter, and there is an author and subject index.

The arrangement makes the bibliography difficult to use, because related items are not listed together. A chronological arrangement would, for example, make the history chapter much more useful. Because of the alphabetical arrangement, the reader must rely on the subject index, which, unfortunately, is quite inadequate. A few examples: there is not a heading "Ballet, Denmark," though "Ballet, Place" is used, and there are three citations to "Bourno[n]ville, August[e]"; title of literary works mentioned are not always listed in the index; there is no consistency in assigning subject headings-a reader can find entries under bottomless dancing, burlesque, strippers, striptease, and topless dancing. Not even see also references are given.

The author states that this bibliography was compiled using the various commercial databases. This could explain the paucity of citations to dance journals and some peculiar selections. For example, the literature section appears to include any item with dance in the title, including references to Anthony Powell's A Dance to the Music of Time, to John Arden's Sarjeant Musgrave's Dance, and to an article about Romeo and Juliet which, according to the annotation, "investigates the significance of Romeo's not dancing .... in two scenes." There are peculiar absences as well. The compiler has included Walter Terry's poorly received biography of Auguste Bournonville (misspelled in the index), but not the monumental 1979 English translation of Bournonville's autobiography.-M.C.

\section{Research Guide to Biography and Criticism:}

World Drama. Walton Beacham, ed.

Washington, D.C.: Research Pub., [1986]. 742p. \$65 (ISBN 0-93383-06-7). LC 86-6441.
This companion to the Research Guide to Biography and Criticism: Literature (1985) is "designed to assist students in narrowing and researching topics for term papers and essay exams" (pref.). There are 146 playwrights, from Aeschylus to Peter Handke, including Shakespeare; each entry is signed by the compiler. The selections, made with the assistance of professors and librarians, are limited "to those authors who are the most studied" (pref.) and for whom material in English is available.

The entries include a brief summary of the author's life; an often incomplete list of his works; an overview of biographical sources; evaluations of selected biographies; a discussion of autobiographical sources, where appropriate; an annotated list of selected criticism; and in some cases a list of other sources, such as concordances and bibliographies.

Although this guide could be useful to students doing preliminary research, it needs to be used with caution. The listings of the authors' works are not consistent. Occasionally a complete bibliography is given, often only selected works. Some entries list only dramatic works and some include other genres. This selection seems to be at the compiler's whim; the bibliography for John Gay, for instance, is so detailed that it includes recordings of The Beggar's Opera, while the bibliography for Shakespeare does not list all of his plays and lists none of his poems. Foreign titles are listed only in English translations. Some of the critical items cited do not seem appropriate for undergraduate term papers. For the price, one would expect more careful editing. $-M$.C.

Theatre Companies of the World. Colby $\mathrm{H}$. Kullman and William C. Young, eds. Westport, Conn.: Greenwood, 1986. 2v. [979p.] \$95 (ISBN 0-313-21456-5). LC 84-539.

This work was planned by Young and, after his death in 1979, continued by coeditor Kullman. As a useful and thorough guide to current theatrical companies of the world, it is a fitting memorial to Young. 
The editors in chief assigned nine broad geographic areas to different editors, who then solicited contributions for individual countries from scholars or drama critics familiar with the theater of that country. All entries are signed, and brief biographical information is included for each contributor.

The volumes are arranged by geographic area, then alphabetically by country; theatrical companies for individual countries are listed alphabetically. The information for each company includes the address, a statement about its significance, a brief history, a description of the facilities available, the sources of funding, and future plans. Only the most important American companies are discussed; others are covered in Weldon B. Durham's American Theatre Companies, also published by Greenwood in 1986. There are general introductory essays for each area or country, discussing the present theatrical conditions. The reader learns, for example, that German theater productions start on time. The editors include a selective bibliography for each of the major areas, and there is an index covering the individuals and companies mentioned in the text. - M.C.

White, D. Jerry. Early English Drama, Everyman to 1580. Boston: G. K. Hall, 1986. 289p. (ISBN 0-8161-8338-4). LC 86-370.

The author, an associate professor of English at Central Missouri State University, has compiled a "selective, annotated bibliography of resources for the study of the drama of British playwrights during the period roughly from 1495 to $1580^{\prime \prime}$ (pref.) There are sections on bibliographies, both subject and play lists; collections of plays; general criticism; and critical studies of individual plays and playwrights.

The material listed was published from 1691 through 1982 (the vast majority of criticism is twentieth century), and consists of books, articles, and dissertations; some non-English-language criticism is included. Entries are arranged in chronological order within each subdivision. There is an index of authors, playwrights, titles, and subjects. Plays in collections are analysed and listed in the index, so it can also be used to locate copies of plays, an additional boon. This bibliography should be useful to anyone doing research in this area.-M.C.

\section{POLITICAL SCIENCE}

Austin, Eric W. Political Facts of the United States Since 1789. New York: Columbia Univ. Pr., 1986. 518p. \$45 (ISBN 0-23106094-7). LC 86-2605.

The compilation concentrates on statistics picturing U.S. politics and government $1789-1985$. The focus is national election statistics with more than three hundred pages devoted to them. The rest of the volume presents names of cabinet members, heads of branches of the U.S. Armed Forces, ambassadors to selected countries, demographic information, salaries of various government officials, etc.

The advantage of the volume is convenience. The older information is available from a variety of reference sources, e.g., Statistical Abstracts, Historical Statistics of the United States, Notable Names in American History, America at the Polls, etc. The more current information is even more scattered. Here, much relevant material is brought together and updated.

The sources for each table are listed at the back of the volume. $-E . M$.

World Encyclopedia of Peace. Exec. eds., Ervin Laszlo and Jong Youl Yoo; honorary ed. in chief, Linus Pauling. Oxford, New York: Pergamon, [1986]. 4v. illus. $\$ 250$ (ISBN 0-08-032685-4). LC 86-25520.

Contents: v.1-2, Articles; v.3, Treaties,

Chronology of the Peace Movement, Nobel Peace Prize Laureates; v.4, Peace Institutes and Organizations, bibliography, list of contributors, journals, name and subject indexes.

This impressive set commemorates both the fortieth anniversary of the United Nations and the International Year of Peace (1986). It was created on the initiative of Young Seek Choue, founder/chancellor of Nyung Hee University in South Korea, and the groundwork was done by the university's Institute of International Peace Studies, headed by Jong Youl Yoo. The in- 
ternational editorial board consists of twenty-three scholars from east and west Europe, the United States, Canada, and Costa Rica, and there are more than two hundred contributors.

An excellent introduction to the field of peace research is provided by Peter van den Dungen's essay, "Peace Encyclopedias of the Past and Present," a critical bibliographical piece that interprets encyclopedias broadly to include bibliographies, biographies, general surveys, and encyclopedic treatments of peace relative to economics, history, medicine, literature, and law. It is followed by a dictionary arrangement of more than 470 signed articles and biographies of deceased figures, with brief bibliographies for each. Bibliographies stress, but are not limited to, English-language published and unpublished materials. Biographies emphasize the significant peace-related activities, with brief treatment of strictly biographical data. Scope is wide-ranging, with articles on caudillismo, domino theory, and Jonathan Swift, in addition to the more expected topics. Most articles achieve a balanced tone and treatment. In some, the editorial slant is clearly labelled, e.g., "Militarism: Marxist-Leninist Critique", other articles, not labelled, show their contributor's philosophy-Marxist, feminist, etc.-perhaps more clearly than is desirable in a work of this caliber.

The third volume offers full texts of the work of thirty-nine significant international treaties signed between 1919 and 1981 , a chronology of the peace movement from the mid-nineteenth century until 1983, and full biographies of all Nobel Peace Prize laureates. Profiles of national and international peace institutes and organizations, a classed bibliography of some one thousand items, a list of contributors and their articles, a name index for authors of cited works, and a subject index to the four-volume set constitute the final volume.

As the introductory essay on peace encyclopedias suggests, this is a unique endeavor in many ways; it is also a fine achievement and deserves a place in all but the smallest reference collections.D.G.

\section{HISTORY}

American Studies: An Annotated Bibliography. Jack Salzman, ed. Cambridge, New York: Cambridge Univ. Pr., 1986. $3 v$. [2,058p.] \$175 (ISBN 0-521-32555-2). LC 86-17164.

Contents: v.1, Anthropology and Folklore-Literature; v.2, MusicSociology; v.3, Indexes.

Begun under the auspices of the American Studies Association as a revision of an earlier ASA work, this bibliography evolved into a completely new work. This set contains more than six thousand entries for works published $1900-83$ with a cultural emphasis in American studies. Each entry includes a descriptive annotation with a complete bibliographic citation of the work. The items are arranged in eleven sections: Anthropology and Folklore, Art and Architecture, History, Literature, Music, Political Science, Popular Culture, Psychology, Religion, Science, Technology and Medicine, and Sociology. Excluded are articles, works that are primarily theoretical or methodological, and most biographies. Each section includes a preface that describes the basic bibliographic sources in that particular discipline. The section is then broken down further into appropriate subsections that vary from section to section. Volume 3 comprises author, title, and subject indexes, which enhance the use of the set as a reference work. Recommended as an invaluable source for materials covering the breadth of American culture.-L.S.S.

\section{Henige, David P. Serial Bibliographies and} Abstracts in History: An Annotated Guide. Bibliographies and Indexes in World History, 2. Westport, Conn.: Greenwood, 1986.220 p. $\$ 35$ (ISBN 0-31325070-7). LC 85-27178.

The author has been generous in his definition of history and lists 874 " bibliographies which address in whole or in part any aspect of the past" (pref.). Both separately published bibliographies and those appearing regularly in journals are listed in alphabetical order by title. Annotations describe the form and content of a recent issue; indexes and cross-references pro- 
vide broad subject access. National bibliographies and those that list only books have been excluded.

This is a handy and compact guide, most useful for its subject access to a large number of current bibliographies in history, literature, religion, physical sciences, social sciences, and philosophy. The guide does not provide much bibliographic information on the works cited: no descriptions of previous issues, dates of publication, or name changes are provided; in many cases, the publisher is omitted. Because it only describes a very recent issue of each publication, Serial Bibliographies and Abstracts in History is most useful for the reader looking for current articles on a particular subject. Those looking for less current books and articles will need to use this guide in conjunction with other reference works that provide a more complete description and publishing history. Although much of the information provided is also listed in the Guide to Reference Books, this work is recommended to libraries for its lists of bibliographies in journals and for its comprehensive subject access. - S.S.

Historical Dictionary of the Third French Republic, 1870-1940. Ed. by Patrick H. Hutton; Amanda S. Bourque and Amy J. Staples, assistant editors. Historical Dictionaries of French History. Westport, Conn.: Greenwood, 1986. 2v. \$125 (set) (ISBN 0-313-22080-8). LC 84-15737.

One in the series Historical Dictionaries of French History, this book claims to be "the first comprehensive work of reference in its field, in either French or English" (pref.). More than 750 entries cover all aspects of the history of France, political, economic, social, and cultural, from 1879 to 1940 . The work was a joint venture of 153 U.S. and Canadian scholars and students of the Third Republic. The dictionary aims to serve beginning students with articles of varied length from 150word summaries to 3,000-word essays. Each entry gives the essential facts on the topic, "some evaluation of the meaning or significance of the topic," bibliographies, and cross-references to other relevant entries in the dictionary.

Appendix 1, "Entries Classified by
Topic," gives a general idea of the coverage and serves also as an index, although there is a more detailed index at the end of the second volume. Two other appendixes list the presidents and premiers of the Third Republic and give a three-page chronology of the republic.

Individual entries are of unequal quality. Some have an annoying tendency to categorize the subject in meaningless epithets. Many biographical entries are already repeated in many other dictionaries. For this type of publication to be successful, it would need a unifying theme other than the historical period. The "Major Interpretive Essays" under several broad topics, such as politics, provide to some extent the background for individual entries. The work is as much a reflection of our time as that of a historical period. Terminology, such as secular humanism, mirrors our current preoccupations rather than elucidating life under the Third Republic.-J.S.

\section{Historical Times Illustrated Encyclopedia of} the Civil War. Patricia L. Faust, ed. New York, Harper \& Row, [1986]. [850p.] $\$ 39.95$ (ISBN 0-06-181261-7). LC 8645095.

A useful one-volume encyclopedia on the Civil War, the Historical Times Illustrated Encyclopedia of the Civil War has taken advantage of much current research for its brief entries. Composed of 2,200 entries, the emphasis is on biographical information for people important not only in the military effort, but those important to the time. In addition to biographical entries, articles cover a wide spectrum of important topics including campaigns, battles, naval action, political activity, social and economic themes, newspapers, places, events, etc. The articles are clear, concise, and richly illustrated with maps and photographs. Cross-references are provided to the correct form of an entry, and small capitals are used within articles to indicate an entry under that term. The articles are signed, and brief biographies of the contributors are included. Recommended for all libraries as a supplement to, rather than a replacement of, other important onevolume Civil War dictionaries and encyclopedias.-L.S.S. 


\section{SCIENCE AND TECHNOLOGY}

Chen, Ching-cheh. Scientific and Technical Information Sources. $2 \mathrm{~d}$ ed. Cambridge, Mass.: MIT Pr., 1987. 835p. \$55 (ISBN 0262-03120-5). LC 86-7310.

The announced intent of this work is that it serve the scientific information professional or library school student as a one-volume reference guide. Secondly, it is intended to serve the practicing scientist or engineer as a reference manual. Essentially, the volume presents a classed list of about 5,300 print, nonprint, and online sources, with about half the entries carrying brief annotations. The entries are organized in twenty-three categories by type of material, e.g., guides to the literature, dictionaries, treatises, and within these categories by subject. They are listed alphabetically within each subdivision by title rather than by author or editor.

The compilation is provided with a detailed table of contents, a corporate and personal author index, and a title index. There do not appear to be cross-references to assist the reader not certain of a title. Since entries are unnumbered, references are to a page number, which can cause the user to have to scan closely at times to identify the needed entry.

The choice of titles for inclusion is somewhat ambiguous. The compiler states that inclusion is "necessarily selective, although in most categories no obvious attempt has been made to present only the best of the sources available" (pref.). She rightly points out the monumentality of her task and the importance of including current material. The closing date for inclusion was February 1986.

The strength of this compilation lies in its wide scope and voluminous size. Surely every science librarian will find references in this volume to relevant materials with which he or she is not familiar. However, this great breadth of coverage is also a source of weaknesses. No one person unaided can do a thorough job of covering this much material. Consequently, despite claims to currency, a number of important recent publications are omitted while older references abound. Some standard reference tools have been omit- ted, and the categorical placement of others is difficult to comprehend. The "Treatises" section shows little knowledge of mathematics.

In short, this compilation is vast, useful, and uneven. It is most appropriate for experienced science librarians as a meaty supplementary source. $-M . K$.

Childress, James F., and others. Biolaw: A Legal and Ethical Reporter on Medicine, Health Care, and Bioengineering. Frederick, Md.: Univ. Publs. of Am., 1986- . (loose-leaf) v.1- . (ISBN 0-89093-940-3). LC 86-35054.

v.1, Resource Manual; v.2, Updates, Special Sections; v.2, Microfiche Supplement (v.1-2, \$295/yr.; v.3, \$475/yr.).

This publication should be useful for students and researchers interested in medicine, law, public health, public policy, biotechnology, bioethics, and related fields. Volume 1 includes descriptive information, with chapters entitled "Introduction to the Legal System and Bioethics" and "Reproductive Choices." A good subject index leads to specific topics within the volume, such as AIDS and confidentiality.

The second volume consists of bimonthly updates, with highlights of recent legislation and current issues. A broad range of topics is covered including "Access to Health Care for the Poor" and "Providing Needles to Drug Addicts." A cumulative index in this volume leads to articles in both volumes 1 and 2 .

Volume 3 includes microfiche copies of more than two thousand pages of primary source material, thus far. This publication is expensive but pulls together a lot of information in interdisciplinary areas. Volumes 1 and 2 could be used without the microfiche supplement in large academic libraries where much of the source material would already be in the collection.S.B.

\section{NEW EDITIONS, SUPPLEMENTS, ETC.}

RSANB, 1926-1958 (Retrospective South African National Bibliography for the Period 1926-1958) (Pretoria: The State Library, $1985,2 v$.) describes material published in 
South Africa between Sidney Mendelssohn's South African Bibliography to the Year 1925 (Guide DD176) and South African National Bibliography (Guide AA1075), which began in 1959.

The British Library has published Catalogue of Seventeenth Century Italian Books in the British Library (1986. 3v.) for books printed in Italy or outside Italy in Italian, 1601-1700. This work continues the Short Title Catalogue of Books Printed in Italy . . . 1565 to 1600 (Guide AA900). Appended is the list, "Books Destroyed by Enemy Action, 1939-1945."

T. F. Hoad has based his Concise Oxford Dictionary of English Etymology (Oxford: Clarendon Pr., 1986, 552p.) on C. J. Onion's Oxford Dictionary of Etymology (Guide AD44). The Concise is very much shortened but still concentrates on "the route by which each headword [or entry word] entered the English language" (introd.).

The newly published fascicle 3, D-E, of Dictionary of Medieval Latin from British Sources by R. E. Latham and D. R. Howlett (Guide AD556) includes a bibliography of all sources used in the Dictionary, p.xi-lxi.

The Ayer Directory of Publications (Guide AE31), which became IMS . . . Ayer Directory of Publications (Guide AE32) has now become Gale Directory of Publications with the 119th edition, 1987. This edition was prepared by IMS but published by Gale; the next edition will be edited and published by Gale.

The Waterloo Directory Series (for phase one see Guide AE89) has issued phase two, Waterloo Directory of Irish Newspapers and Periodicals 1800-1900 (Waterloo, Ont.: North Waterloo Academic Pr., 1986., 838p.), which covers all fields and all types of serials published in Ireland. At least one location is given for each title.

The Gesamtverzeichnis osterreichischer Dissertationen (Guide AH28) has issued a Systematisches Register covering 1966-75 supplying a classed index, a name index, and a geographical index. With volume 35 (1986) Aslib has changed its title to reflect the inclusion of abstracts of theses, to Index to Theses with Abstracts Accepted for Higher Degrees by the Universities of Great Britain and Ireland and the Council for $\mathrm{Na}$ - tional Academic Awards (Guide AH61). The index will appear quarterly.

The Dictionary of A frican Historical Biography by Mark R. Lipschutz and R. Kent Rasmussen is now in a second edition (Berkeley, Calif.: Univ. of Calif. Pr., 1986, 328p.; 1st ed., 1978, Guide AJ104). This means that entries new (with a cut-off date of 1980 ) to the second edition are grouped in a supplementary section, p.258-90, and "other changes have been restricted to updates of original entries and insertions of more recent bibliographical citations" (foreword).

With the twenty-fifth edition of Wer Ist Wer? (Guide AJ211), photographs of many biographees have been added, along with a necrology and a calendar list of birthdays (without the year of birth).

Religion Index One: Periodicals (Guide BB41) has made some changes with volume 18 (1986): dropped the author abstracts, changed publication schedule to annual with one semiannual issue, and moved the book reviews to a separate publication, Index to Book Reviews in Religion. This new title is bimonthly, beginning January/February 1986, and offers more indexing than RIO did, including a reviewers index. The Encyclopedia of American Religions by J. Gordon Melton (Guide BB57) is now in a second edition, having updated and expanded the first edition to include some 1,350 groups and increased the number of indexes (Detroit: Gale, 1987, 899p.).

Holman's Handbook to Literature (Guide BD62) is available in a fifth edition compiled by William Harmon (New York: Macmillan, 1986, 647p.). Much of the text has been revised with new articles added; most articles have at least one bibliographical reference. Also additional is an appendix for proper names and where they can be located in the text. The Princeton Handbook of Poetic Terms, edited by Alex Preminger (Princeton, N.J.: Princeton Univ. Pr., 1986, 309p.) is more than a spin-off of the articles on poetic genres, modes, and forms from the Princeton Encyclopedia of Poetry and Poetics (Guide BD314). Many of the articles have been rewritten, there are additional ones, and bibliographies have 
been updated. "A Select Reading List" is appended as a basic "First Find-List for the Best and Most Recent Work on the Topics Given" (p.301).

Three new volumes of the Dictionary of Literary Biography (Guide BD416) have been issued: v.51, Afro-American Writers from the Harlem Renaissance to 1940, ed. Trudier Harris (1987); v.56, Victorian Prose Writers before 1867 , ed. William B. Thesing (1987); v.55, German Fiction Writers, 1914-1945, ed. James Hardin (1987).

Volume 7 of the Manual of the Writings in Middle English (Guide BD517) was published in 1986 and covers John Gower, Piers Plowman, Travel and Geographical Writings, and Works of Religious and Philosophical Instruction.

A Comprehensive Bibliography of Victorian Studies 1970-1984 compiled by Brahma Chauduri is an expanded version of the Cumulative Bibliography of Victorian Studies 1976-1980 (Guide BD532). The indexing has been corrected; books and articles missed in the earlier compilations have been added. Unfortunately the Annual Bibliography of Victorian Studies (Guide BD531) is still needed if one is looking for reviews, since the cumulation dropped them.

Bernth Lindfors has compiled a supplement to Black American Literature in English (Guide BD746) covering the years 1977-81 with some 2,700 entries (N.Y.: Africana, 1986, 382p.). The Oxford Companion to German Literature (Guide BD846) is in a second edition edited by Mary Garland (New York: Oxford Univ. Pr., 1986, 1,020p.). Much of the new material covers literary trends since the 1960 s and the impact of literary and cultural affairs.

Gordon Samples' The Drama Scholars' Index to Plays and Filmscripts (Guide BG38) has a third volume now covering through 1983 and also including materials omitted in volumes 1-2 (Metuchen, N.J.: Scarecrow Pr., 1986, 416p.). The London Stage 1920-1929: A Calendar of Plays and Players (Metuchen, N.J.: Scarecrow, 1984, 3v.) continues the London Stage 1890/99-1910/19 (Guide BG89-91). Denis Gifford has added a supplement for films for 1971-1985 to his earlier volume The
British Film Catalogue (Guide BG213) in order to update it (New York, Oxford: Facts On File, 1986).

Patricia Ballou's seminal Women: A Bibliography of Bibliographies (Guide CC498) is revised to eliminate superseded titles and to add 1980-85 materials as well as those 1978 and 1979 publications that were inadvertently omitted (Boston: G. K. Hall, 1986, 268p.). Films for, by and about Women (Guide CC523) compiled by Kaye Sullivan now has a supplement called series 2 , which is a continuation to 1980 (Metuchen, N.J.: Scarecrow, 1985, 780p.).

The International Folklore Bibliography, Internationale Volkskundliche Bibliographie (Guide CF49) added an English-language subject index with Jahre 1979/1980 (1985) and a complete list of journals searched. Jarhe 1981/82 is to add a French language subject index. The editors are developing a computerized index in conjunction with the Modern Language Association to improve the indexing and possibly to attach it as a subfile to the MLA database.

The Dictionary of Business Biography (Guide $\mathrm{CH} 280$ ) is complete now with volume 5, S-Z (1986), and a Supplement: Indexes, Contributors, Errata, edited by David J. Jeremy (London: Butterworths, 1986, $120 \mathrm{p}$.). The indexes are to industries, companies, trade associations, businesspeople.

Part $3 / 1$ for central and eastern and northern Europe was published for Peter Truhart's Regents of Nations (Guide CJ231; Munich: K. G. Saur, 1986), and ABC-Clio has published the fifth and final volume of the Historical Periodicals Directory (Guide DA31; 1986. 227p.). This volume does include Australia and New Zealand and provides cumulative subject and title indexes.

Also covering Australia is the addenda 1784-1850 to volumes 1-4 of John Alexander Ferguson's Bibliography of Australia (Guide DF6; Canberra: National Library of Australia, 1986, 706p.). This means all titles omitted in volumes 1-4 as well as addenda already printed are cumulated into a single volume.

Volume 5 of the Guides to Sources for British History Based on the National Register of 
Archives (Guide DC294) covers Private Papers of British Colonial Governors 1782-1900 and senior officials of the Colonial Office (London: HMSO, 1986).

$\mathrm{ABC}$-CLIO has issued four more bibliographies for countries in its World Bibliographical series: no.20, Sri Lanka, by Vijaya Samaraweera $(1987,194 \mathrm{p}$.$) ; no.71,$ Portugal, by P. T. H. Unwin (1987, 269p.); no.73, Syria, by Ian J. Seccombe (1987, 341p.); and no.76, Barbados, by Robert B.
Potter and Graham M. S. Dann (1987, 356p.). Each follows the usual pattern of citations arranged under broad subject headings, four- or five-sentence annotations, and an author, title, subject index.

Directory of American Research and Technology is the new name of Industrial Research Laboratories of the United States (Guide EA196); this change occurred with the twenty-first edition. The content and format, however, are very much the same. 


\section{ACQUISITION PERSPECTIVES}

4. We have established a reputation for accuracy in billing and shipping to your specifications. Invoices arranged alphabetically by author or title, or numerically by purchase order, and separate billing available upon request for Grant Funds, Title II, gifts, etc. Book House error rate last year was less than one percent of the books we delivered.

The best value is accurate fulfillment of your orders.

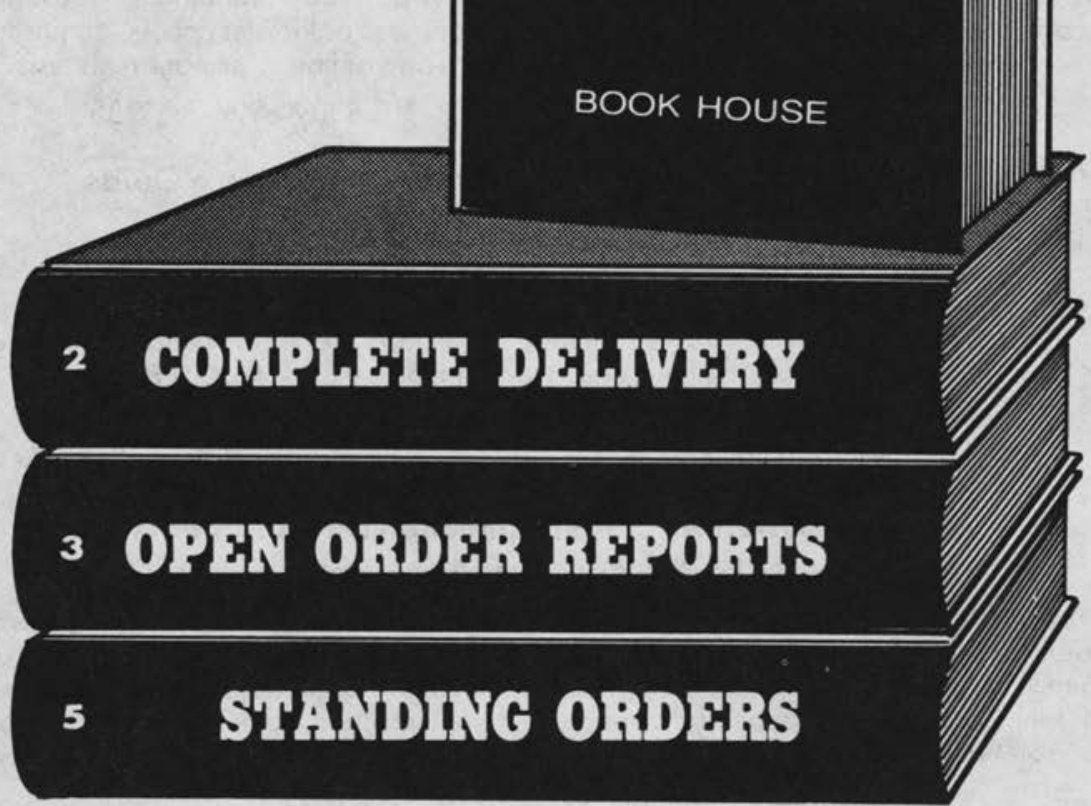

CALL TOLL-FREE TODAY

1-800-248-1146

In Canada \& Michigan

CALL COLLECT (517) 849-2117

OCLC Vendor No. 17397

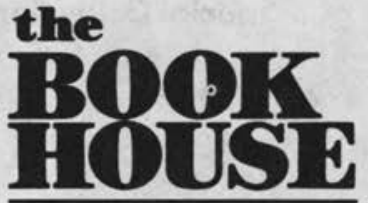

JOBBERS SERVING LIBRARIES WITH ANY BOOK IN PRINT SINCE 1962

208 WEST CHICAGO STREET

JONESVILLE, MICHIGAN 49250 


\title{
colection Your Development Collection N
}

\author{
Guide for the Development and Management of Test Collections \\ with Special Emphasis on Academic Settings \\ Prepared by the ad hoc subcommittee on Test Collections \\ of the Education and Behavioral Sciences Section, ACRL
}

"Any question a librarian might have on the subject of test collections appears to have been answered in the Guide." (Library Journal) Contains chapters on planning the test collection, scope of the collection, bibliographic control of tests, problems of access, acquisitions

of tests, circulation policies, staffing patterns and online information on tests.

$\$ 12.00$ pbk.; ACRL member $\$ 9.00 \quad 69 p$. $0-8389-6926-7 \quad 1985$

\section{Women's Studies in Western Europe: A Resource Guide}

\section{Edited by Stephen Lehmann and Eva Sartori}

A country-by-country directory of organizations, libraries, bibliographies, diaries, publishers, journals, and bookshops providing information about women's studies.

Also describes women's studies courses and research in Western Europe and the development of the Fawcett Library, the oldest and largest library in Britain devoted entirely to the study of women.

$\$ 18.00$ pbk.; ACRL member $\$ 15.00 \quad$ 129p. $0-8389-7307-01986$

\section{Curriculum Materials Center Collection Development Policy}

Prepared by the Education and Behavioral Sciences Section, ACRL

A model collection development policy for curriculum materials centers will help librarians define their collection development programs and provide guidance in building and maintaining their materials and equipment collections. Details objectives of the collection, clientele to be served, scope and boundary of the collection, review sources, personnel

roles and responsibilities, selection criteria, gifts, weeding policy, and ILL policy.

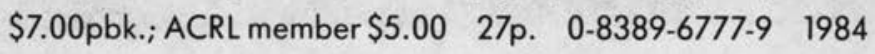

\section{Special Collections in College Libraries CLIP Note \#6 Compiled by Christine Erdmann}

Contains sample documents from college libraries on projects, publicity, financial support, archives, preservation, and use policies.

\$18.00pbk.; ACRL member $\$ 15.00$ 95p. $0-8389-7004-41986$

Association of College and Research Libraries

a division of the American Library Association

c/o ALA Publishing Services, Order Department

50 East Huron Street · Chicago, Illinois 60611-2795 